\title{
Bacterial and primary production under hypertrophic conditions
}

\author{
Norbert Kamjunke*, Wiebke Böing, Hanno Voigt \\ Dresden University of Technology, Institute of Hydrobiology, D-01062 Dresden, Germany
}

\begin{abstract}
Many highly eutrophic waters are dominated by Cyanobacteria non-edible for zooplankton. This dominance of large phytoplankton and its exudation as well as the low biomass of small phytoplankton lead to a high ratio of exudation to edible primary production. As bacteria can effectively use exudates, they could be an important alternative food source for zooplankton. We investigated primary production (PP) in various size fractions and bacterial production (BP) in the hypertrophic Bautzen reservoir (Germany) in order to test whether (1) high PP can promote high BP and (2) BP can amount to similar values as particulate PP of the edible fraction. The main part of PP was produced by non-edible colonies of Microcystis spp. in summer and fall. The dynamics of BP and PP showing maximum activities in July and October were closely coupled. The strong relationship between BP and PP $\left(\mathrm{r}^{2}=0.98\right)$ indicates that allochthonous DOC (dissolved organic carbon) should be of little importance for bacteria. Consequently, PP was their main DOC source, but exudation could not cover bacterial organic carbon demand at the maxima of $\mathrm{BP}$. The mean ratio of $\mathrm{BP}$ to $\mathrm{PP}$ was $3.5 \%$, a low value typical for hypertrophic waters. However, BP amounted to similar or higher values than particulate PP of the edible fraction with respect to carbon production in summer and fall. Since the dominating daphnids are considered to be able to graze effectively on bacteria, it must be assumed that bacteria should be an equally important food source for Daphnia as edible phytoplankton.
\end{abstract}

KEY WORDS: Bacterial production · Exudation - Primary production · Hypertrophic lake $\cdot$ Biomanipulation

\section{INTRODUCTION}

Today it is widely accepted that heterotrophic bacteria may contribute substantially to secondary production in aquatic ecosystems. As bacteria can effectively use exudates of phytoplankton (Larsson \& Hagström 1979, Cole et al. 1982) and according to the concept of the microbial loop (Azam et al. 1983), they are assumed to be an important link between dissolved organic matter and higher trophic levels. The relationship between bacterial and primary production (BP and $\mathrm{PP}$, respectively) was intensively investigated during the last $15 \mathrm{yr}$ (review by Cole et al. 1988 , Baines \& Pace 1991), mainly focusing on the question of how much of the PP is channeled to the bacteria.

However, if one considers BP and PP as a food source for zooplankton, the ratio of BP to PP alone is not very

•E-mail: nk6@rcs.urz.tu-dresden.de suitable because many zooplankters cannot feed on large phytoplankton. Especially in highly eutrophic waters with dominant Cyanobacteria, small phytoplankton edible for zooplankton contributes only to a minor part to PP. Therefore, direct zooplankton grazing on phytoplankton is of minor importance under hypertrophic conditions (Behrendt \& Nixdorf 1991). On the other hand, high PP can provide a considerable exudation. This exudation by mainly non-edible phytoplankton and the low PP of edible phytoplankton lead to a high ratio of exudation to edible PP and, consequently, bacteria possibly could be an equally important food source for zooplankton as phytoplankton.

The aim of this study was to test the hypotheses that (1) high PP can promote high BP and (2) BP can amount to similar values as edible PP. The test was based on a determination of $\mathrm{PP}$ in various size fractions and $\mathrm{BP}$ in the hypertrophic Bautzen reservoir (Germany) between April and December 1995. 


\section{MATERIALS AND METHODS}

Bautzen reservoir (Saxony, Germany) is a hypertrophic, polymictic reservoir with a surface area of $5.33 \mathrm{~km}^{2}$ and a mean depth of $7.4 \mathrm{~m}$. Since 1981, the food web has been top-down manipulated (biomanipulation) by drastic enhancement of piscivorous fish stocks up to $30-50 \%$ of adult fish biomass. As a consequence, the reduced predation pressure of planktivorous fish enabled the development of high biomasses of Daphnia galeata during extended periods of the year (Benndorf 1995).

Investigations were carried out at the deepest part of the reservoir from April to December 1995. Phytoplankton and zooplankton samples were taken with a 21 Ruttner bottle in vertical series $(2.5 \mathrm{~m}$ spacing). Phytoplankton was examined alive, subsamples were preserved with Lugol's solution and counted by the Utermöhl (1958) sedimentation technique. Biomass of large Microcystis colonies was estimated after disintegration by ultrasonication. Zooplankton samples were concentrated using a $55 \mu \mathrm{m}$ net. Large Daphnia were caught by vertical hauls with $500 \mu \mathrm{m}$ nets with flowmeters inside. Mesozooplankton samples were preserved in $4 \%$ sugar formalin solution (Haney \& Hall 1973). Animals were counted in a Kolkwitz chamber and grouped in categories of body length of $50 \mu \mathrm{m}$. The biomass was estimated on the basis of speciesspecific length/weight regressions (Bottrell et al. 1976).

PP was measured using the ${ }^{14} \mathrm{C}$ method according to Vollenweider (1969). Samples were taken from 5 depths ( 0 to $3 \mathrm{~m}$ or 0 to $5 \mathrm{~m}$ ) and prefiltered through a $450 \mu \mathrm{m}$ net in order to remove the most effective filterfeeding zooplankton, the large daphnids. Two light glass bottles and 1 dark one $(125 \mathrm{ml})$ per depth were spiked with $1 \mathrm{ml} \mathrm{NaH}{ }^{14} \mathrm{CO}_{3}\left(6.5 \mu \mathrm{Ci} \mathrm{ml}{ }^{-1}\right.$, Isocommerz) and were incubated in situ for $4 \mathrm{~h}$ around noon. Incorporation was stopped with formalin $(0.3 \%$, final concentration). To determine total activity, triplicates of $0.5 \mathrm{ml}$ from each bottle were mixed with $15 \mu \mathrm{l} \mathrm{Car-}$ bosorb (Packard). $15 \mathrm{ml}$ of each sample was filtered through a $30 \mu \mathrm{m}$ net, the filtrate through $1 \mu \mathrm{m}$ Nuclepore filters, and this filtrate through $0.2 \mu \mathrm{m}$ Nuclepore filters. The size fraction retained by the nets was resuspended with distilled water and filtered onto $8 \mu \mathrm{m}$ cellulose nitrate filters (Sartorius). All filtrations using filters were carried out at low vacuum pressure of $20 \mathrm{kPa}$. In order to remove the remaining $\mathrm{NaH}^{14} \mathrm{CO}_{3}$ $10 \mathrm{ml}$ of the $<0.2 \mu \mathrm{m}$ filtrate was acidified with $50 \mu \mathrm{l}$ $25 \%$ hydrochloric acid and aerated for $30 \mathrm{~min}$. Duplicates of $2 \mathrm{ml}$ of this $<0.2 \mu \mathrm{m}$ filtrate were used for counting After adding $10 \mathrm{ml}$ Ultima Gold (Packard) to each scintillation vial, radioactivity was measured using a Liquid Scintillation Analyser (1600 TR, Packard). The external standards ratio method was used to correct for quenching.
Phytoplankton size fractions $>30 \mu \mathrm{m}$ are considered to be not accessible for the dominating zooplankton in Bautzen reservoir, as under most circumstances Daphnia galeata cannot feed on particles larger than about $30 \mu \mathrm{m}$ (Burns 1968, Wagner pers. comm.). The $1-30 \mu \mathrm{m}$ size fraction represents the edible part of $P P$, the $0.2-1 \mu \mathrm{m}$ fraction the small free-living bacteria (no autotrophic picoplankton $<1 \mu \mathrm{m}$ was found), and the $0.2 \mu \mathrm{m}$ filtrate the EOC (extracellular organic carbon) released by phytoplankton. The ${ }^{14} \mathrm{C}$ incorporation in the light bottles was corrected by the dark bottle values for phytoplankton, but not for bacteria and EOC (Watanabe 1980). Because the addition of formalin increased the activity in the $<0.2 \mu \mathrm{m}$ filtrate, unkilled subsamples of the bottles from $0.5 \mathrm{~m}$ depth were filtered immediately after the incubation. Using this ratio of filtrates from unkilled to killed samples for each sampling day, the filtrates from the killed samples of the other depth were corrected. Dissolved inorganic carbon was estimated from alkalinity and phenolphthalein value according to DEV (1993). Daily rates of primary production ( $\mathrm{PP}_{\mathrm{d}}$ ) were calculated using Eq. (1) (Meffert \& Overbeck 1985):

$$
P P_{d}=P P_{\text {inc }} \times I_{d} / I_{\text {inc }}
$$

where $\mathrm{PP}_{\mathrm{In}}$ is the carbon assimilation during the time of incubation, $I_{d}$ and $I_{1 n c}$ the global radiation recorded by a pyranograph (Richter) at the shore station during the day and the incubation, respectively.

$\mathrm{BP}$ was measured using ${ }^{14} \mathrm{C}$-leucine according to Simon \& Azam (1989). Pooled samples of the 5 depths of PP measurement were used. Triplicates of $15 \mathrm{ml}$ and 1 formalin killed control (3.7\%, final concentration) were spiked with $0.54 \mu l{ }^{1.4} \mathrm{C}$-leucine $\left(200 \mu \mathrm{Ci} \mathrm{ml}{ }^{-1}\right.$, Sigma, $30 \mathrm{nM}$ final concentration). After incubation for $1 \mathrm{~h}$ in the dark at in situ temperature, incorporation was stopped with formalin, and $2 \mathrm{ml} \mathrm{50 \%} \mathrm{TCA} \mathrm{(tri-}$ chloracetic acid) was added to each bottle. Samples were boiled for $30 \mathrm{~min}$, cooled down, and filtered onto $0.2 \mu \mathrm{m}$ Nuclepore filters. Filters were rinsed twice with $1 \mathrm{ml} \mathrm{5 \%}$ TCA and once with distilled water, and counted as described above. Carbon production was calculated using the equations of Simon \& Azam (1989). To obtain an areal daily production, BP (mg C $\mathrm{m}^{-3} \mathrm{~h}^{-1}$ ) was multiplied by the mean depth and $24 \mathrm{~h}$ (Kirchman \& Hoch 1988, Pace \& Cole 1994). This appears to be correct because the reservoir is relatively shallow and polymictic, and the magnitude of diurnal variation is regarded as relatively low in comparison to BP (Riemann \& Søndergaard 1984). Our own experiments showed neither systematic variations over depth nor significant differences between day and night. Bacterial organic carbon demand (BOCD) was estimated by assuming a growth yield of $50 \%$ for bacteria (Cole et al. 1982, Cole \& Pace 1995). 


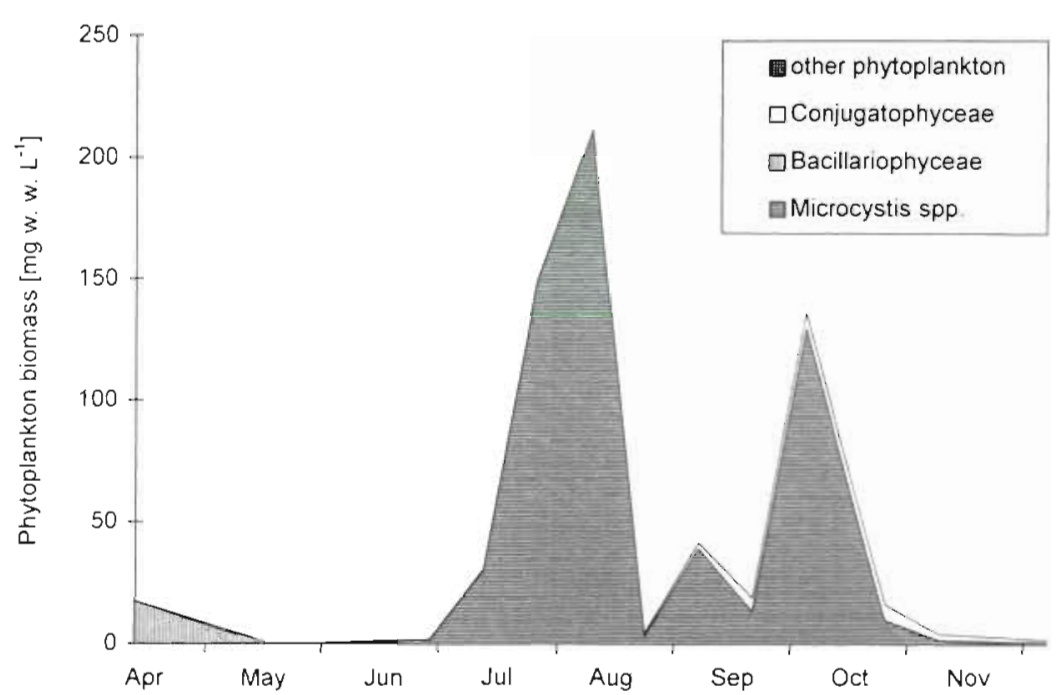

Fig. 1 Vertical averages of phytoplankton biomass (w. w. = wet weight) in Bautzen reservoir 1995

time, the main part of PP was gained in the $>30 \mu \mathrm{m}$ fraction owing to mass developments of Asterionella formosa in April, of Microcystis spp. from July until October, and of Staurastrum quadridentatum and A. formosa in winter. Only in May did the 1-30 $\mathrm{mm}$ fraction dominate due to an occurrence of Rhodomonas spp. and Stephanodiscus hantzschii. The share of EOC in total PP ranged from 2 to $13 \%$ (mean $6.5 \%$ ). The $0.2-1 \mu \mathrm{m}$ fraction varied between 0.1 and $2 \%$ (mean $1 \%$ ) of total PP and was always of minor importance. However, this fraction did not represent the whole uptake of EOC by bacteria since a considerable part of bacterial activity was determined in the $>1 \mu \mathrm{m}$ fraction (leucine uptake in the described size fractions estimated without heating of samples; Kamjunke unpubl. data).

\section{RESULTS}

The dynamics of phytoplankton biomass (Fig. 1) showed moderate values in spring owing to a development of Asterionella formosa, and low values during a marked clear water phase until June. From July to October, Microcystis spp. dominated the biomass, showing a first peak in July and August, a drastic decline at the end of August probably due to a short nutrient exhaustion at the surface (soluble reactive phosphorus was undetectable), and a second peak in October. Low biomass in winter was yielded by Staurastrum quadridentatum and $A$. formosa. Zooplankton biomass (Fig. 2) was dominated by Daphnia galeata which achieved very high values. On an annual basis, it contributed $61 \%$ to total biomass. Only in spring and late summer were other groups remarkably abundant. During summer and fall, no zooplankton appeared in sufficient numbers capable of feeding on particles larger than $30 \mu \mathrm{m}$. The length of $D$. galeata ranged between 0.83 and $1.4 \mathrm{~mm}$ on average. The intersetulae investigated by using 1 and $1.5 \mathrm{~mm}$ long animals varied between 0.3 and $0.4 \mu \mathrm{m}$ and between 0.36 and $0.56 \mu \mathrm{m}$, respectively.

The dynamics of PP (Fig. 3) mainly followed that of phytoplankton biomass. Production was relatively high compared to biomass during the clear water phase and at the end of August due to the high light penetration. During most of the

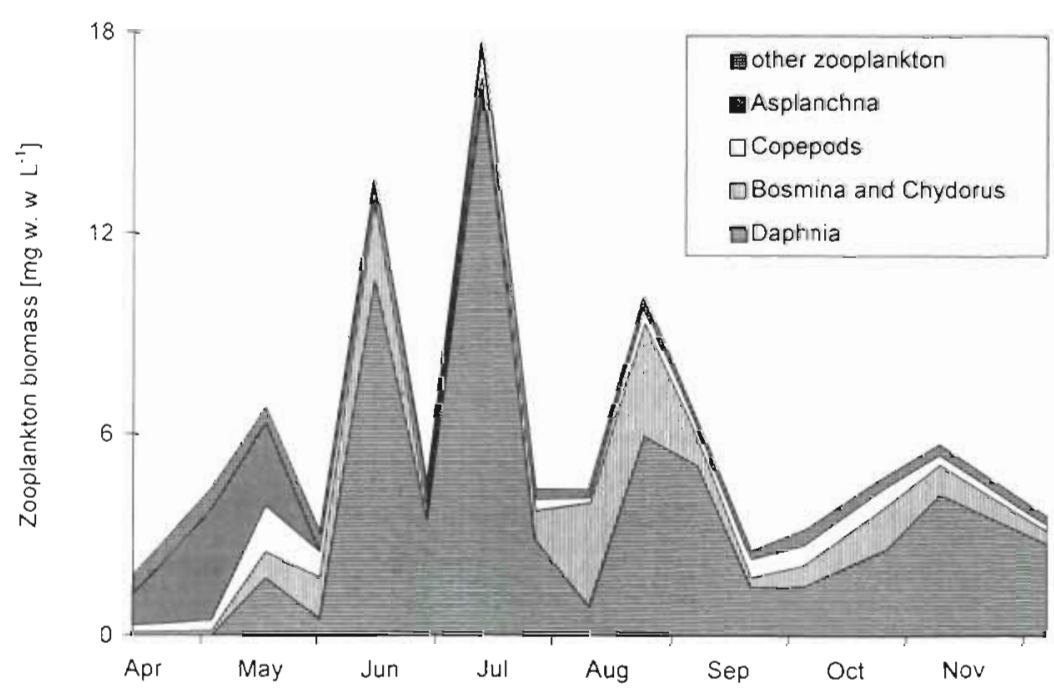

Fig. 2. Vertical averages of zooplankton biomass (w. $w$. = wet weight) in

\footnotetext{
Fig. 2. Vertical averages of zooplankton biomass (w. w. = wet weight) in
Bautzen reservoir 1995
}

BP during the same period (Fig. 4, solid line) was low until June, reached 2 maxima in July and October, and was low again in winter. The dynamics of $\mathrm{BP}$ and PP were coupled very closely, and the maxima occurred exactly on the same days in July and October. Since BP increased more strongly than PP, a nonlinear regression was fitted through the points (Fig. 5). The equation of the highly significant relationship $\left(r^{2}=0.98\right)$ consists of not only a linear term. including a low, positive $y$-intercept but also a small square term. The ratio of $\mathrm{BP}$ to $\mathrm{PP}$ ranged between 1 and $8 \%$ with an average of $3.5 \%$. 


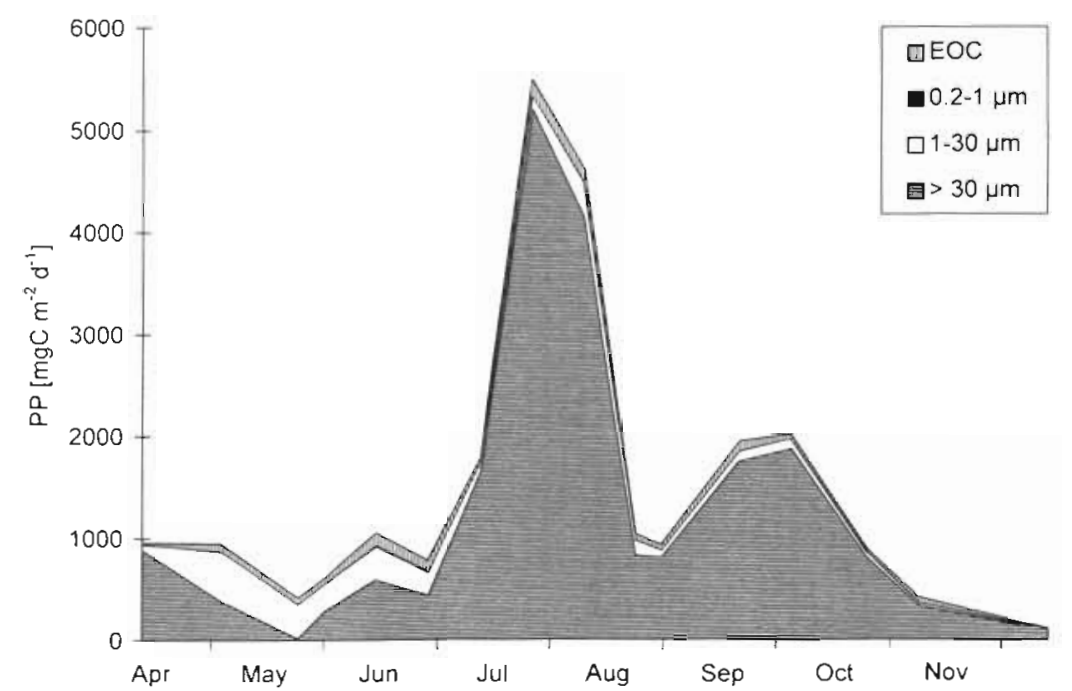

Fig. 3. Dynamics of planktonic primary production (PP) in Bautzen reservoir 1995

EOC exceeded BOCD in May and June, was almost equal to BOCD in September, and became higher again in winter (Fig, 6). However, EOC covered only 20 to $30 \%$ of BOCD during the blooms of Asterionella formosa in April and of Microcystis spp. in July and August and in October. In contrast to the close relationship between BP and total PP, there was no significant relationship between BP and edible PP (Fig. 4). In comparison with $\mathrm{BP}$, edible $\mathrm{PP}$ was much higher until June. But from July onwards, BP achieved a similar order of magnitude and exceeded edible PP at its maxima in July and October.

\section{DISCUSSION}

$\mathrm{PP}$ in Bautzen reservoir amounted to very high values, similar to those reported by Köhler (1992) and Kamjunke et al. (1996). As shown by Kamjunke et al. (1996), the dominance of large Microcystis spp. in the reservoir during summer and fall was not a result of grazing by daphnids and, therefore, the high biomass of Microcystis spp. as well as the low share of edible phytoplankton should be caused by bottom-up factors. However, the strong top-down pressure on small phytoplankton decreased the proportion of edible PP in total PP as well. The mean share of EOC in total PP was relatively low $(6.5 \%)$ and thus corresponded to low values found by Bell et al. $(1983 ; 5 \%)$ or Köhler (1992; 7.1\%). This phenomenon was described to be typical for highly eutrophic waters (Vollenweider 1969, Baines \& Pace 1991). BP was in the range reported in the literature (Cole et al. 1988) and met approximately the values of Robarts et al. (1994) who found 20 to $422 \mathrm{mg} \mathrm{C} \mathrm{m}^{-2} \mathrm{~d}^{-1}$. The mean ratio of BP to PP $(3.5 \%)$ was relatively low compared with the literature, in which a mean of $30 \%$ (Cole et al. 1988) or a range of 6 to $25 \%$ (Pace \& Cole 1994) were suggested. This indicates that an overestimation of $\mathrm{BP}$ due to the calculation of areal daily BP seems to be unlikely. The low ratio supports the findings of Jeppesen et al. (1992) who observed a lower proportion in hypertrophic waters. Other authors also reported low ratios, e.g. $5 \%$ in a mesotrophic lake (Bell \& Kuparinen 1984), 4 and $2.5 \%$ in a eutrophic and a hypertrophic lake, respectively (Jeppesen et al. 1992), and $2 \%$ in a hypertrophic lake (Robarts \& Wicks 1990).

The closely coupled dynamics of BP and PP were also observed by other investigators (Bell et al. 1983, Kirchman \& Hoch 1988). Similar to this study, Robarts et al. (1994) measured the highest values of BP during Cyanobacteria blooms. The nonlinear relationship between BP and PP $\left(\mathrm{r}^{2}=0.98\right)$ was stronger than usually reported (Robarts et al. 1994: $\mathrm{r}^{2}=0.58$; Gajewski \& Chróst 1995: $\mathrm{r}^{2}=0.77$; both linear regressions). This indicates that PP was the main dissolved organic carbon (DOC) source for bacteria, and allochthonous DOC should be of low importance. As non-edible phytoplankton produced the main part of PP, espe-

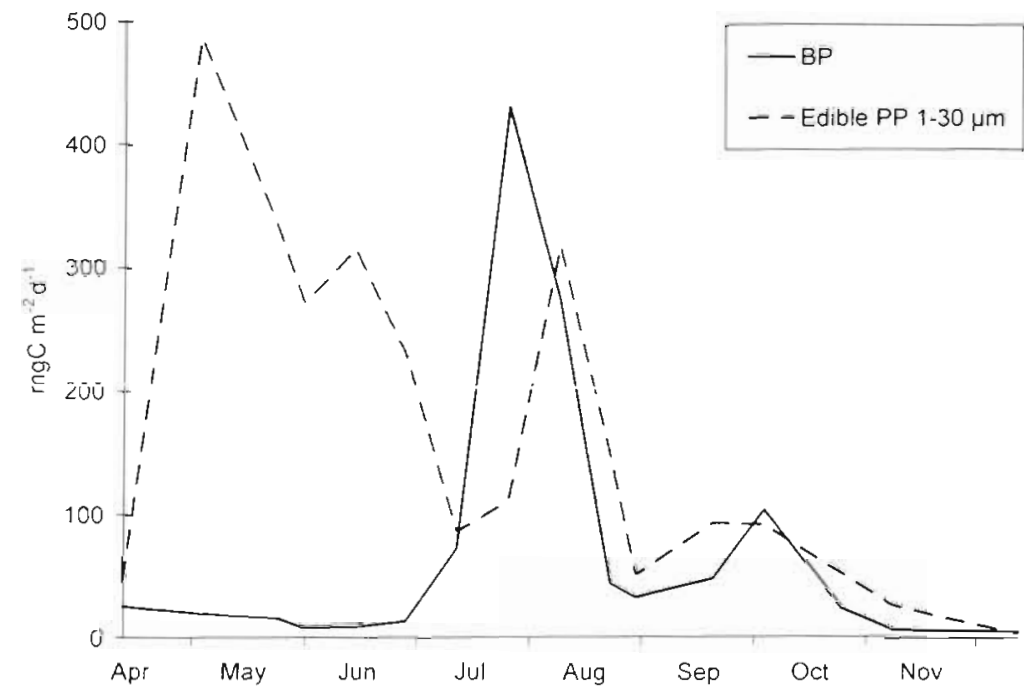

Fig. 4. Dynamics of heterotrophic bacterial production (BP) in Bautzen reservoir 1995 and comparison with edible primary production (PP) 


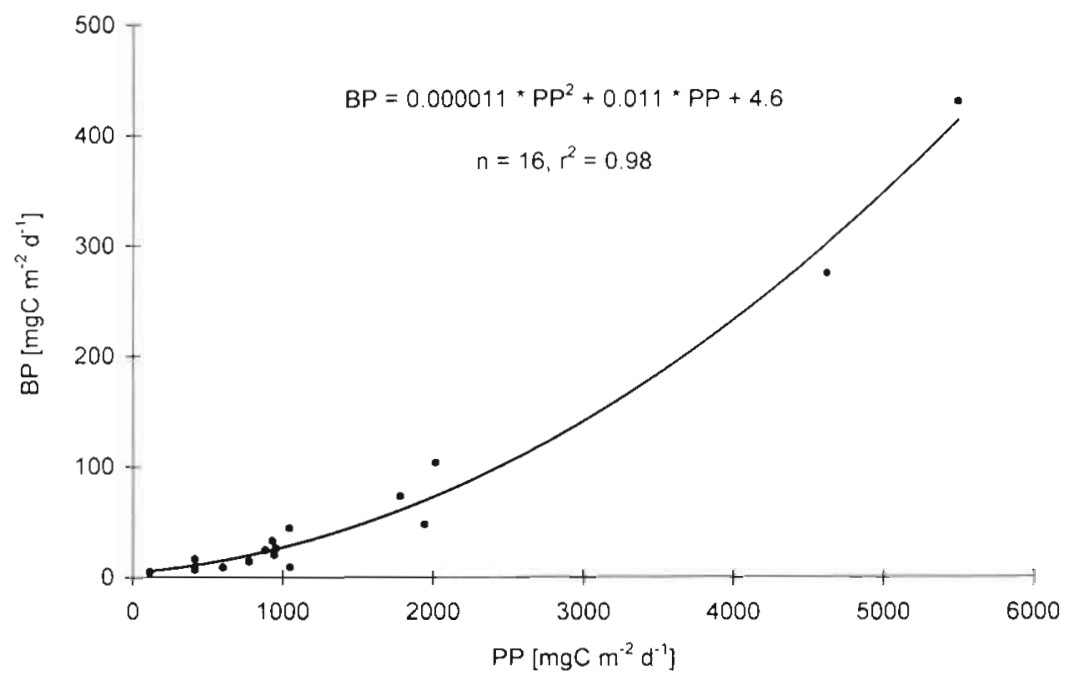

Fig. 5. Bacterial production (BP) as a function of primary production (PP) the case in Bautzen reservoir, and there was no significant relationship between BP and edible PP (Fig. 4). The most important carbon source for bacteria besides EOC seemed to be senescence of phytoplankton during the decline or the stationary growth phase of strong blooms. Christoffersen et al. (1990) calculated that lysis products of Cyanobacteria can cover roughly $20 \%$ of BOCD. During a Phaeocystis bloom, all BOCD could be explained by phytoplankton cell lysis (Brussaard et al. 1995). In the case of Bautzen reservoir, excess bacterial carbon demand (BOCD - EOC) amounted to only $0.6 \%$ and $0.3 \%$ of phytoplankton carbon at the summer maxima of BP (end of July and early August, respectively), assuming $11 \%$ carbon content of phyto- cially during the maxima (Fig. 3), the carbon of this fraction should be most important for bacteria. But no conclusion could be made concerning the way in which bacteria were supplied with the fixed carbon of the phytoplankton.

When EOC exceeded BOCD in May and June (Fig. 6), uptake of EOC obviously was limited by other processes, for instance grazing. During the clear water phase, bacterial numbers decreased similar to BP (Kamjunke unpubl. data). During other periods, EOC could not explain totally the BOCD. This is in agreement with Baines \& Pace (1991) who estimated that EOC contributed less than half of the carbon required for bacterial growth in most pelagic systems. Christoffersen et al. (1990) observed even a share of only 4 to $9 \%$. One reason for this difference to BOCD could be that EOC was underestimated due to the immediate uptake by bacteria, especially by large and attached bacteria in the $>1 \mu \mathrm{m}$ fraction. In addition, bacteria may use other carbon sources than exudation. Byproducts of animal feeding, which can amount to up to $10-50 \%$ of carbon fixation of phytoplankton (Jumars et al. 1989), are assumed to also be able to contribute substantially to bacterial growth. The observed high biomasses of Daphnia galeata should be a good prerequisite for an intense carbon flow of that nature. But sloppy feeding (release of DOC during grazing of zooplankton on phytoplankton) and digestion should be of greater importance only when a sufficient part of PP is available for zooplankton. This was not plankton biomass (Jeppesen et al. 1996). Moreover, biomass-specific production values were among the lowest of the year on these 2 days, indicating that the physiological status of the phytoplankton was poor. Therefore, lysis products of phytoplankton were an explainable source for additional BOCD besides EOC in Bautzen reservoir.

The high BP supported by carbon of mainly non-edible phytoplankton, and the low share of edible PP in total PP caused by the dominance of large Microcystis spp. as well as the strong top-down pressure on small phytoplankton, led to relatively high ratios of $\mathrm{BP}$ to edible PP during summer and fall. The high values of

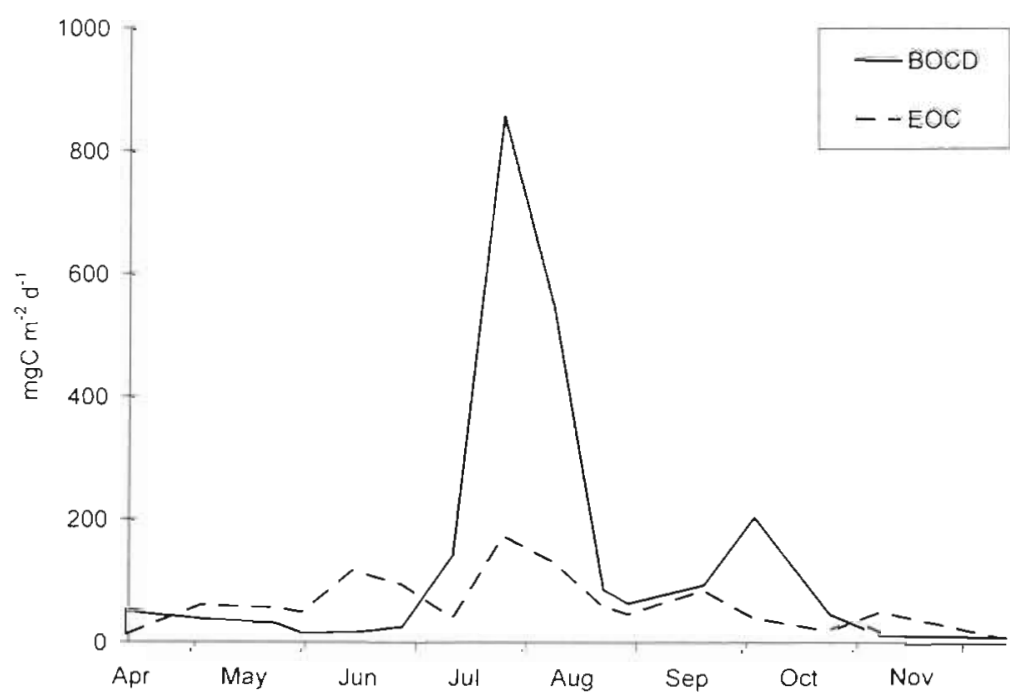

Fig. 6. Comparison of bacterial organic carbon demand (BOCD) with extracellular organic carbon (EOC) 
$\mathrm{BP}$ equalling or exceeding the edible PP from July onwards should be of great importance for feeding of Daphnia galeata. This species dominated the zooplankton biomass in Bautzen reservoir. Daphnia can effectively graze on bacteria as a direct alternative food source (Riemann 1985). Up to $84 \%$ (Güde 1988) and $86 \%$ (Christoffersen et al. 1990) of BP was shown to be grazed by daphnids. The plankton community structure determines the fate of BP: if daphnids are consistently abundant, grazing by Daphnia is likely to be the predominant fate of BP (Pace et al. 1990). Daphnia can effectively 'break' the microbial loop, and direct grazing on bacteria by macrozooplankton can funnel a higher fraction of BP up the food web than grazing by protozoans due to respiratory losses at each trophic step (Pace et al. 1990). In Bautzen reservoir, the biomass of $D$. galeata was very high (Fig. 2). If we calculate an effective filtration rate for $D$. galeata according to the equations of Kamjunke et al. (1996), this clearance rate ranged between 0.04 and $0.67 \mathrm{~d}^{-1}$ (average $0.25 \mathrm{~d}^{-1}$ ) during the period from mid-May to October. Jeppesen et al. (1996) did not find a significant difference in $D$. galeata specific clearance rate on bacterioplankton and phytoplankton. Moreover, the intersetulae of $D$. galeata were very small 10.3 to $0.5 \mu \mathrm{m}$ ), revealing that $D$. galeata was able to feed on the majority of bacterial biomass. Therefore, it must be assumed that bacteria should be an equally important food source for Daphnia as edible phytoplankton under the conditions in Bautzen reservoir. This mechanism contributes to high standing stocks of Daphnia and, therefore, to a higher stability of biomanipulation. However, further research is necessary to investigate which parts of $\mathrm{BP}$ and $\mathrm{PP}$ are really ingested by zooplankton.

Acknowledgements. We thank J. Benndorf for helpful discussions and the opportunity to work in the project, $R$. Koschel for preparation of $\mathrm{NaH}^{14} \mathrm{CO}_{3}$, E. Mach for radioassaying, and $\mathrm{K}$. Ockenfeld for technical support. Furthermore, we thank J. Benndorf, T. Mehner, and anonymous reviewers for constructive suggestions on the manuscript. This paper is based on research project 0339549 of the Federal Ministry of Education and Research (BMBF), Germany. A grant by the Federal Environmental Foundation of Germany was given to N.K.

\section{LITERATURE C $\perp \perp$ U}

Azam F, Fenchel T, Field JG, Gray JS, Meyer-Redl LA, Thingstad $F$ (1983) The ecological role of water-column microbes in the sea. Mar Ecol Prog Ser 10:257-263

Baines SB, Pace ML (1991) The production of dissolved organic matter by phytoplankton and its importance to bacteria: pattern across marine and freshwater systems. Limnol Oceanogr 36:1078-1090

Behrendt H. Nixdorf B (1991) Estimation of phytoplankton production and loss processes in a eutrophic shallow lake. Verh Int Verein Limnol 24:893-896
Bell RT, Ahlgren GM, Ahlgren I (1983) Estimating bacterioplankton production by measuring $[3 \mathrm{H}]$ thymidine incorporation in a eutrophic Swedish lake. Appl Environ Microbiol 45:1709-1721

Bell RT, Kuparinen J (1984) Assessing phytoplankton and bacterioplankton production during early spring in Lake Erken, Sweden. Appl Environ Microbiol 48:1221-1230

Benndorf J (1995) Possibilities and limits for controlling eutrophication by biomanipulation. Int Rev Gesamten Hydrobiol 80:519-534

Bottrell HH, Duncan A, Gliwicz ZM, Grygierek E, Herzig A, Hilbricht-Ilkowska A, Kurasawa H, Larson P, Weglenska A (1976) A review of some problems in zooplankton production studies. Norw J Zool 24:419-456

Brussaard CPD, Riegman R, Noordeloos AAM, Cadee GC, Witte H, Kop AJ, Nieuwland G, van Duyl FC, Bak RPM (1995) Effects of grazing, sedimentation and phytoplankton lysis on the structure of a coastal pelagic food web. Mar Ecol Prog Ser 123:259-271

Burns CW (1968) The relationship between body size of filter feeding cladocera and the maximum size of particle ingested. Limnol Oceanogr 13:675-678

Christoffersen K, Riemann B, Hansen LR, Klysner A, Sorensen HB (1990) Qualitative importance of the microbiol loop and plankton community structure in a eutrophic lake during a bloom of Cyanobacteria. Microb Ecol 20: $253-272$

Cole JJ, Findlay S, Pace ML (1988) Bacterial production in fresh and saltwater: a cross system overview. Mar Ecol Prog Ser 43:1-10

Cole JJ, Likens GE, Strayer DL (1982) Photosynthetically produced dissolved organic carbon: an important carbon source for planktonic bacteria. Limnol Oceanogr 27: $1080-1090$

Cole JJ, Pace ML (1995) Why measure bacterial production? A reply to the comment by Jahnke and Craven. Limnol Oceanogr 40:441-444

DEV (1993) Deutsche Einheitsverfahren zur Wasser- Abwasserund Schlammuntersuchung. Verlag Chemie, Weinheim

Gajewski AJ, Chróst RJ (1995) Production and enzymatic decomposition of organic matter by microplankton in a eutrophic lake. J Plankton Res 17:709-728

Güde $H$ (1988) Direct and indirect influences of crustacean zooplankton on bacterioplankton in Lake Constance Hydrobiologia 159:63-73

Haney JF, Hall DJ (1973) Sugar-coated Daphnia: a preservation technique for cladocera. Limnol Oceanogr 18 $331-333$

Jeppesen $E$, Søndergaard $M$, Jensen JP, Mortensen $E_{\text {, }}$ Sortkaer $O$ (1996) Fish-induced changes in zooplankton grazing on phytoplankton and bacterioplankton: a longterm study in shallow hypertrophic Lake Søbygaard J Plankton Res 18:1605-1625

Jeppesen E, Sortkjaer O. Søndergaard M, Erlandsen M (1992) Impact of a trophic cascade on heterotrophic bacteriopiankion prucuction in tivo shallow fish-manipulatod lakes. Arch Hydrobiol Beih Ergebn Limnol 37:219-231

Jumars PA, Penry DL, Baross JA, Perry MJ, Frost BW (1989) Closing the microbial loop: dissolved carbon pathway to heterotrophic bacteria from incomplete ingestion, digestion and absorption in animals. Deep Sea Res 36:483-495

Kamjunke N, Herbst RF, Wagner A, Benndorf J (1996) Size distribution of primary production in a whole-lake biomanipulation experiment under hypertrophic conditions. Arch Hydrobiol 138:259-271

Kirchman DL. Hoch MP (1988) Bacterial production in the Delaware Bay estuary estimated from thymidine and 
leucine incorporation rates. Mar Ecol Prog Ser 45: $169-178$

Köhler J (1992) Influence of turbulent mixing on growth and primary production of Microcystis aeruginosa in the hypertrophic Bautzen Reservoir. Arch Hydrobiol 123: 413-429

Larsson U, Hagström A (1979) Phytoplankton exudate release as an energy source for the growth of pelagic bacteria. Mar Biol 52:199-206

Meffert ME, Overbeck J (1985) Dynamics of chlorophyll and photosynthesis in natural phytoplankton associations. Il. Primary productivity, quantum yields and photosynthetic rates in small Northgerman lakes. Arch Hydrobiol 104:363-385

Pace ML, Cole JJ (1994) Primary and bacterial production in lakes: are they coupled over depth? J Plankton Res 16: $661-672$

Pace ML, McManus GB, Findlay SEG (1990) Planktonic community structure determines the fate of bacterial production in a temperate lake. Limnol Oceanogr 35:795-808

Riemann B (1985) Potential importance of fish predation and zooplankton grazing on natural populations of freshwater bacteria. Appl Environ Microbiol 50:187-193

Responsible Subject Editor: G. Bratbak, Bergen, Norway
Riemann B, Sondergaard M (1984) Measurement of diel rates of bacterial secondary production in aquatic environments. Appl Environ Microbiol 47:632-638

Robarts RD, Arts MT, Evans MS, Waiser MJ (1994) The coupling of heterotrophic bacterial and phytoplankton production in a hypertrophic, shallow prairie lake. Can J Fish Aquat Sci 51:2219-2226

Robarts RD. Wicks RJ (1990) Heterotrophic bacterial production and its dependence on autotrophic production in a hypertrophic African reservoir. Can J Fish Aquat Sci 47 $1027-1037$

Simon M, Azam F (1989) Protein content and protein synthesis rates of planktonic marine bacteria. Mar Ecol Prog Ser 51:201-213

Utermöhl H (1958) Zur Vervollkommnung der quantitativen Phytoplankton-Methodik. Mitt Int Verein Limnol 9:1-38

Vollenweider RA (ed) (1969) A manual on methods for measuring primary production in aquatic environments. IBP Handbook No. 12, Blackwell Scientific Publications, Oxford

Watanabe $Y(1980)$ A study of the excretion and extracellular products of natural phytoplankton in Lake Nakanuma, Japan. Int Rev Gesamten Hydrobiol 65:809-834

Manuscript received: October 2, 1996

Revised version accepted: April 4, 1997 